\title{
投資理論を考慮した小売業均衡売場面積の推計に関する研究 ESTIMATING BALANCED SALES AREAS OF RETAIL TRADE WITH CONSIDERATION INVESTMENT THEORY
}

\author{
趙 世 晨*, 萩島 哲** \\ Shichen ZHAO, Satoshi HAGISHIMA
}

\begin{abstract}
It is pointed out that the depression factor of the retail trade is a decrease in the sales efficiency because of the excessive expansion of sales areas. The purpose of this study is to propose a decision model of the retail trade sales areas, and to clarify the determinants of optimum scale quantitatively. Thirst of all, we explained the mechanism of the investment decision based on the neoclassical investment theory, and constructed an estimate model of sales areas. Secondly, we applied the estimate model to the cities in Kyushu. As the results, we made clear two points. 1) The presumption value of the parameters using in the model was admitted statistically significant. 2) The validity of the model was shown in the application results of each city.
\end{abstract}

Keywords: Retail trade, Sales areas, Investment theory, Maximum function, Optimum scale 小売業，売場面積，投資理論，効用最大化，最適規模

1. はじめに

\section{1 背景と目的}

小売業界は, 今窮地に追い込まれている. 近年, 相次いで郊外に 出店し，これまで勝ち組と言われていた大型ショッピングセンター や，人気専門店の一部にまで，業績下方修正や減益決算企業が続出 している。これらの商業施設に影響を受けてきた中小小売店や商店 街においては, さらに梁刻な状況で, 多くの商店街で空き店舗が増 加し続けている．このような小売業低迷の要因として，経済不況の 深刻化による消費の冷え込み, 大店立地法施行による駆け込み出店, 低価格競争による粗利益率の低下，過剩投資 (売場面積の過剩拡大) による販売効率の低下が挙げられる. 今後, 新規出店或いは都市商 業政策として, 都市における小売業の規模をどのようにコントロー ルしていくかが, きわめて重要な課題となる.

そこで，本研究は，新古典派投資理論に基づいて，消費者による 家計効用最大化行動，企業による利潤最大化行動，長期的投資行動 の 3 つの行動を定式化し, 都市における小売業の均衡売場面積（最 適規模）の推計モデルを構筑する，次いで，九州地方の都市におけ る 6 時点の時系列データを用いて，モデルのパラメータの推計を行 い, 均衡売場面積の決定要因について考察を行う. さらに, 九州各 県及び福岡都市圈の 6 つ都市の均衡売場面積を推計し，それぞれの
実績と比較しながら，近年の動向を把握する.

\section{2 既往研究}

これまで商業施設における床面積または立地の予測に関する研究 は数多く行われている．特に理論モデルの分野では古くから数え切 れないほどの研究がある，その代表的なものが，八フモデルと経済 学に立脚したモデルに関する研究である.

八フモデルに関する研究として以下のものがある、斎藤氏ら"は， 従来の静的なハフモデルでは商業床面積の空間配置は外生的に決定 されているが故に，計画的出店の考慮はできるものの，自然増床と いった店舗の更新行動のメカニズムをモデルの中で表現できていな いことを指摘している. よって，この点を補完すべく，売場面積投 凟のメカニズムを内生化したダイナミカルハフモデルを用いて商業 床分布を計算している。

次に，経済学に立脚したモデルとして，奥村氏ら ${ }^{21}$ は売店の質 的魅力の更新行動を，新古典派投資理論を用いて説明し，比較的簡 単な仮定の下で推計モデルを構筑している. そして, そのモデルを 活用して，自治体や商店街組織による商店街活性化策についての理 論的な考察を試みている．小林氏ら ${ }^{3)}$ は，地方都市で提供される非 日常的サービスの品質, 価格, 多様性という視点から，地方都市活 力の経時的な変動状況を分析している. 具体的には, 地方都市圈の

* 九州大学大学院人間環境学研究院 助教授 $\cdot$ 博士 (工学 $)$

** 九州大学大学院人間環境学研究院 教授. 工博
Assoc. Prof., Faculty of Human-Environment Studies, Kyushu Univ., Dr. Eng. Prof., Faculty of Human-Environment Studies, Kyushu Univ., Dr. Eng. 
サービス市場活力がサービスの質, 価格, 及び内容の豊富さによっ て規定されると考え, サービス市場の活力が地方都市に置かれてい る環境の変動と対応して長期的に変動するメカニズムについて分析 した．さらに，サービス市場に関わるパネルデータを用いて，市場 活力の長期変動パターンについて実証的な分析を行っている.

以上のように, 理論モデルに関する研究では, 現実のメカニズム を考慮し，数学的に簡略化するのは一般的であり，数值例の計算や 実験を用いてモデルの妥当性を検証する例が多い，本研究は，これ らの既往研究を踏まえて，新古典派経済学における投資理論を考慮 し，企業の長期累積利潤最大化の視点から企業の投資行動に基づい て，小売業均衡売場面積の推計モデルを構築し，時系列データを用 いてパラメータを推定した上で, 各決定要因の感度分析を行い，九 州各県及び福岡都市圈の各都市の売場面積動向について考察を行う ものである。

\section{3 論文構成}

本論文は, 5 章で構成されている。第 1 章では, 本研究の背景と 意義について述べ, 既往の研究を整理した上で, 本研究の目的を示 した，第 2 章では，新古典派経済学に基づき市場における需給関係 及び企業の利潤最大化から売場面積の投資決定に至るメカニズムを 説明し，推計モデルを構築している，第 3 章では，九州地区の各都 市のパネルデー夕を用いてモデルのパラメータを求める。さらに, 売場面積決定要因の影響度合を検証した，第 4 章では，理論モデル の適用例として, 福岡都市圈各都市の小売業売場面積の最適規模を 推計し, 実績值と比較しながら，近年の動向について考察している. なお，都市圈内の古賀市と前原市について，分析時点において統計 データの久如があったため，分析対象から除外している．第 5 章は， 本論文の内容，結果を要約し，まとめとしている，

\section{2. 均衡売場面積推計モデルの構築}

\section{1 新古典派投資理論の概要}

新古典派投資理論とは(4), 5), 最適資本量の新古典派理論のもとで 構築されたものである．新古典派理論では，家計と企業が表裹一体 とみなされており，投資と消費が同一の経済主体によって行われる という前提のもとで，経済主体が生産活動から得たものを消費する ことにより，その効用を最大化するように行動するということが想 定されており，家計及び企業主体の最適化行動による企業価值の最 大化から決定される最適資本量の決定理論である。つまり，家計は 消費から得る効用を最大化するように行動するに対し，企業はその 現在価值を最大化するように行動する，そうして決定される生産要 素価格によって企業の投資行動が行われるという理論である.

本モデルの構築においては，ミク口経済学的行動理論に基づいた 資本投資の決定理論という点で，モデル自体の理論的根拠を明確に できる上に，実証分析にも耐えうるものと考えている.

\section{2 家計行動・企業投資行動の定式化}

(1) 前提条件

モデル構築は, 以下に示す 5 つの前提条件に沿って行う.

(1) $t$ 期の都市 $i$ には $g$ 種類の業種がある. $t$ 期の都市 $i$ の業種 $g$ には, $M_{g(t)}$ の企業が立地する. 各企業は売場面積 $k_{g(t)}$ の店舗を有し販売 活動を行う。

(2)主体は，家計と企業の 2 つの主体を考える.
(3)各都市に居住する家計は, 自都市内の商品を消費するものとする. (4)家計は効用最大化行動に従って消費する商品の選択を行い，その 結果から需要価格が決定する.

(5)企業は, 家計の効用最大化行動の結果から導かれる需要価格をも とに, 商品の販売を行うと同時に, 利潤最大化行動に従って施設 売場面積の調整（投資・撤退）を行う。その結果から各都市の売場 面積が決定する.

\section{（2）家計行動の定式化}

都市に立地する，ある業種の代表的店舗を考える，そして，家計 は各店舗で販売している商品を購入・消費することで，その効用最 大化を図りながら行動する。このような都市家計が代表的店舗で販 売する商品を需要する場合の効用最大化問題は，CES 型効用関数を 用いて，以下のように定義する。

$$
\max U\left(C_{1(t)}, C_{2(t)}, \cdots \cdots, C_{n(t)}\right)=\left[\sum_{k}^{n(t)}\left(C_{k(t)}\right)^{\rho}\right]^{\frac{1}{\rho}}
$$

ただし，家計所得は各種消費行動の合計と等しいという制約条件 を設ける。この制約条件は，次式となる。

$$
\text { s.t. } \quad \sum_{k}^{n(t)} P_{k(t)} \cdot C_{k(t)}=Y_{(t)}
$$

ここで，記号の意味を次のように定義する。

$U:$ 家計の効用関数,

$t:$ 当該年

$C_{k(t)}$ : 家計が消費する商品（業種）kの需要量,

$n_{(t)}$ : 商品（業種）の数,

$\rho:$ 家計における商品の代替性 $(0<\rho<1)$,

$P_{k(t)}$ : 商品 $k$ の価格 (平均価格)，

$Y_{(1)}$ : 家計所得 (平均),

$N_{(t)}$ : 当該都市における小売業店舖数，

$Q_{(t)}:$ 家計総数 (都市世帯数)，

$q_{g(t)}:$ 商品 $g$ の総需要量,

$\kappa_{g(t)}$ ：企業（店舗）当り売場面積，

$\pi_{g(t)}$ : 単位販売額 (均衡販売額)，

$Z_{g}:$ 生産要素,

$\alpha, \beta:$ パラメータ,

上述の最大化問題をラグランジェ末定乗数法を用いて解くと，家 計が消費する商品 $g$ への需要関数が式(3)のように求まる。なお，こ こで業種に対して区別をつけるために，業種を表す $k$ の変わりに $g$ を使用することとする，以下は同様である.

$$
C_{g(t)}=P_{g(t)}^{\frac{1}{\rho-1}} \cdot Y_{(t)} \cdot\left(\sum_{k}^{n(t)} P_{k(t)}^{\frac{\rho}{\rho-1}}\right)^{-1}
$$

さらに, 平均価格を次式と

$$
\sum_{k}^{n(t)} P_{k(t)}^{\frac{\rho}{\rho-1}}=N_{(t)} \cdot \bar{P}_{(t)}^{\frac{\rho}{\rho-1}}
$$

近似すれば, 式 $(3)$ は，次式のように変形できる.

$$
C_{g(t)}=P_{g(t)}^{\frac{1}{\rho-1}} \cdot Y_{(t)} \cdot N_{(t)}^{-1} \cdot \bar{P}_{(t)}^{\frac{-\rho}{\rho-1}}
$$

$t$ 期における家計総数を $Q_{(t)}$, 総需要量を $q_{g(t)}$ とすれば, 集計的需要 
関数は,以下のようになる.

$$
\begin{aligned}
q_{g(t)} & =Q_{(t)} \cdot C_{g(t)} \\
& =Q_{(t)} \cdot P_{g^{(t)}}^{\frac{1}{\rho-1}} \cdot Y_{(t)} \cdot N_{(t)}^{-1} \cdot \bar{P}_{(t)}^{\frac{-\rho}{\rho-1}}
\end{aligned}
$$

よって, $t$ 期, 都市における業種 $g$ の代表的家計による集計的逆需 要関数は, 以下のように定式化できる.

$$
P_{g(t)}=\left(\frac{Y_{(t)} \cdot Q_{(t)}}{N_{(t)} \cdot q_{g(t)}}\right)^{1-\rho} \cdot \bar{P}_{(t)} \rho
$$

以上のように, 家計効用最大化を図りながら, 各商品（業種）の 需要価格及び総需要量を求めることができる。

\section{（3）企業短期的行動の定式化}

競争市場では, 商品の価格は, 原則として市場の需要と供給の関 係で決まる. 各家計や企業は，この変化する均衡価格を目安として 消費や生産の量を調整している，即ち，競争市場が均衡状態である 時, 需要価格が供給価格と一致し, 需要量は供給量と一致する.

よって, 均衡価格を $p_{g(t)}$, 均衡数量を $q_{g(t)}$ とすると, 均衡販売額 （以下，単位販売額とする) は，

$$
\pi_{g(t)}=P_{g(t)} \cdot q_{g(t)}
$$

となる．これに(7)式を代入すると，次式となる.

$$
\pi_{g(t)}=\left(\frac{Y_{(t)} \cdot Q_{(t)}}{N_{(t)}}\right)^{1-\rho} \cdot\left(\bar{P}_{(t)} \cdot q_{g(t)}\right)^{\prime}
$$

企業の供給水準 $q_{g(t)}$ が売場面積 $k_{g(t)}$, 施設以外の生産要素 $Z_{g} に よ$ り規定されると考える。Cobb-Douglass 型生産関数を用いて, 企 業の生産関数を記述すると。

$$
q_{g(t)}=\kappa_{g(t)}^{\alpha} \cdot Z_{g}^{\beta}
$$

となる. ただし， $\alpha, \beta$ は正のパラメータである.(10)式を(9)に代 入すると, 次式を得る.

$$
\pi_{g(t)}=Z_{g}^{\beta \rho} \cdot\left(\frac{Y_{(t)} \cdot Q_{(t)}}{N_{(t)}}\right)^{1-\rho} \cdot \bar{P}_{(t)}^{\rho} \cdot \kappa_{g(t)}^{\alpha \rho}
$$

この式は，家計と企業の需給関係から，企業は短期的に利潤最大 になる単位（1 企業又は 1 店舗当り）年間販売が決定されることを 示している.

\section{（4）企業長期的行動の定式化}

新古典派経済学におりる投資理論では，企業の投資行動を将来に わたるキャッシュフローの現在価値の最大化問題としてとらえる.

ここで, 企業は, 均衡価格 $p_{g^{(}(t)}$, 均衡数量 $q_{g(t)}$ の商品を販売し, 均 衡販売額 $\pi_{g(1)}$ を今期の売上として計上すると同時に, さらなる売上 向上を目指すべく，諸費用を差し引いた純利益の一部を設備投資費 用として充当する。つまり，長期的な累積利潤を最大化するように 売場面積 $k_{g(t)}$ に対する投資計画 $i_{g(t)}$ を決定すると考える.

ここで，(4）節で使われている記号を次のように定義する.

$$
\begin{aligned}
R_{g(t)} & : \text { 業種 } g \text { の代表的店舗のネットキャッシュフロー, } \\
\tau & : \text { 限界法人税率, } \\
\delta_{i} & : \text { 売上高営業利益率（都市固有の值とする）； } \\
r_{0(t)} & : 1 \mathrm{~m}^{2} \text { 当り建設工事費, }
\end{aligned}
$$

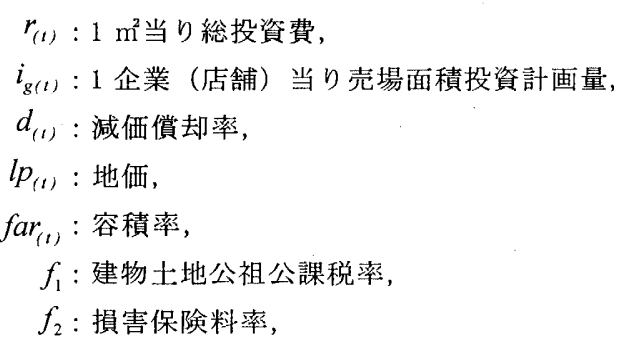

$\mathrm{t}$ 期, 都市 $\mathrm{i}$, 業種 $\mathrm{g}$ の 1 店舗当たりのネットキャッシュフロー(現 金流列)は，以下の式のように表せる.

$$
\begin{aligned}
R_{g(t)} & =(1-\tau) \cdot\left\{\delta_{i} \cdot \pi_{g(t)}-\left(f_{1}+f_{2}\right) \cdot r_{0(t)} \cdot \kappa_{g(t)}\right. \\
& \left.-f_{1} \cdot l p_{(t)} \cdot \kappa_{g(t)} \cdot f a r_{(t)}{ }^{-1}-d_{(t)} \cdot r_{(t)} \cdot \kappa_{g(t)}\right\} \\
& +d_{(t)} \cdot r_{(t)} \cdot \kappa_{g(t)}-(1-\tau) \cdot r_{(t)} \cdot i_{g(t)}
\end{aligned}
$$

企業は無限期における利潤最大化の判断を, DFC 法の正味現在価 值法 (N.P.V) で行うものとする. DFC 法とは，割引キャッシュフロー 法の略称で, 投資期間中のキャッシュフローを全て現在時点に割引 計算するという，理論的な指標である。その割引キャッシュフロー の各年の合計により投資判断する.

一般に, $t$ 年後の割引キャッシュフローは割引率を $\omega(\mathrm{t})$ として,

$$
R_{g(t)} /\left(1+w_{(t)}\right)^{t}
$$

と表せる. よって，無限期までの投資から得られる将来の予想キャッ シュフロー全体の現在価值は，

$$
\begin{aligned}
V_{g} & =\frac{R_{g(1)}}{\left(1+w_{(1)}\right)}+\frac{R_{g(2)}}{\left(1+w_{(2)}\right)^{2}}+\cdots \cdots+\frac{R_{g(t)}}{\left(1+w_{(t)}\right)^{t}} \\
& =\sum_{t=1}^{\infty} \frac{R_{g(t)}}{\left(1+w_{(t)}\right)^{t}}
\end{aligned}
$$

離散時間で表されている上記の式を連続時間で表すと,

$$
\lim _{h \rightarrow \infty}\left(1+\frac{\alpha}{h}\right)^{h}=\exp (\alpha)
$$

より，以下のように表せる。

$$
V_{g}=\int_{0}^{\infty} R_{g(t)} \exp \left(-w_{(t)} \cdot t\right) d t
$$

また，売場面積遷移式を以下のように定義する，つまり，売場面積 の実質的変化量は実質的投資量から実質的消耗量を差引いたものと なる.

$$
\frac{d \kappa_{g(t)}}{d t}=i_{g(t)}-d_{(t)} \cdot \kappa_{g(t)}
$$

上の売場面積遷移式を制約条件とすると，企業の無限期間にわた る利潤最大化問題は次のような動的最適化問題として, (17) 式と (18) のように定式化できる。

$$
\max \left\{\left[\begin{array}{l}
(1-\tau) \cdot\left(\delta_{i} \cdot \pi_{g(t)}\right. \\
-\left(f_{1}+f_{2}\right) \cdot r_{0(t)} \cdot \kappa_{g(t)} \\
\left.-f_{1} \cdot p_{(t)} \cdot \kappa_{g(t)} \cdot f a r_{(t)}{ }^{-1}\right) \\
+\tau \cdot d_{(t)} \cdot r_{(t)} \cdot \kappa_{g(t)} \\
-(1-\tau) \cdot r_{(t)} \cdot i_{g(t)}
\end{array}\right] \cdot \exp \left(-w_{(t)} \cdot t\right) d t\right\}
$$




$$
\text { s.t. } \quad \frac{d \kappa_{g(t)}}{d t}=i_{g(t)}-d_{(t)} \cdot \kappa_{g(t)}
$$

動的最適化問題の解を，ポントリャーギンの最大值原理 ${ }^{5)}$, 6)を用 いて導出する。当期価值ハミルトニアン (Current-va 1 u e Hamiltonian）を以下のように定義する.

$$
H\left(\kappa_{g(t)}, i_{g(t)}\right)=R_{g(t)}+\lambda_{(t)} \cdot\left(i_{g(t)}-d_{(t)} \cdot \kappa_{g(t)}\right)
$$

最適化を特徵づける第 1 の条件は，ハミルトニアンを各時点の操作 変数で微分した導関数がゼロになっていることである、式で表せば 次のようになる.

$$
\frac{\partial H_{(t)}}{\partial i_{g(t)}}=0 \quad \therefore \lambda_{(t)}=(1-\tau) \cdot r_{(t)}
$$

第 2 の条件は, ハミルトニアンの状態变数に関する導関数が, 割 引率と共役変数の積から共役変数の時間微分を差し引いたものに等 しくなるというものである.よって条件式は次のようになる.

$$
\frac{\partial H_{(t)}}{\partial \kappa_{g(t)}}=w_{(t)} \cdot \lambda_{(t)}-\frac{d \lambda_{(t)}}{d t}
$$

上式を(21) 式に代入すると, 次式となる.

$$
\frac{\partial H_{(t)}}{\partial \kappa_{g(t)}}=(1-\tau) \cdot\left(w_{(t)} \cdot r_{(t)}-\frac{d r_{(t)}}{d t}\right)
$$

また,(12) 式及び(19) 式によると,

$$
\begin{aligned}
\frac{\partial H_{(t)}}{\partial \kappa_{g(t)}}= & (1-\tau) \cdot\left\{\delta_{i} \frac{\partial \pi_{g(t)}}{\partial \kappa_{g(t)}}-\left(f_{1}+f_{2}\right) \cdot r_{o(t)}-f_{1} \frac{l p_{(t)}}{f a r_{(t)}}\right\} \\
& +\tau \cdot d_{(t)} \cdot r_{(t)}-(1-\tau) \cdot d_{(t)} \cdot r_{(t)}
\end{aligned}
$$

上記の微分方程式を解くと，売場面積の最適蓄積量(以下，単位 売場面積とする)は，次式の通り求められる。

$$
\kappa_{g(t)}=\alpha \cdot \rho \cdot \delta_{i} \cdot \pi_{g(t)} \cdot\left[\begin{array}{l}
\left\{\left(f_{1}+f_{2}\right) \cdot r_{0(t)}+f_{i} \cdot \frac{l p_{(t)}}{f a r_{(t)}}\right\} \\
+\left(d_{(t)}+w_{(t)}\right) \cdot r_{(t)} \\
-\tau \cdot d_{(t)} \cdot r_{(t)} /(1-\tau)-\frac{d r_{(t)}}{d t}
\end{array}\right]^{-1}
$$

最後の条件は，終端期における資本ストックの価値にここでは，売 場面積の価值) がゼロに等しくなるということである.なぜなら，企 業は終端期の資本保有を減らすことで状況をより改善できることに なる．終端期に企業の保有する資本価值がゼ口になるいう条件は， 次のように書ける。

$$
\lim _{t \rightarrow \infty} \lambda_{(t)} \cdot \kappa_{g(t)} \cdot \exp \left(-w_{(t)} \cdot t\right)=0
$$

また, 都市全体の業種 $\mathrm{g}$ の集計売場面積は, 業種 $\mathrm{g}$ の占舗数を $\mathrm{Mg}$ （t）とし，次式の通り定義する，なお， $\mu_{0}, \mu_{l}, \mu_{2}$ は，正のパラ メータである。

$$
K_{g(t)}=\mu_{0} \cdot M_{g(t)}^{\mu_{1}} \cdot \kappa_{g(t)}{ }^{\mu_{2}}
$$

ここで地価, 容積率, 単位建設工事費, 建築・土地公租公課税率, 損害保険料率, 割引率, 減価償却率については, 建設コスト $\cos t_{(t)}$
として一変数の扱いにすると,(27) 式となる.

$$
\begin{aligned}
\operatorname{cost}_{(t)} & =\left\{\left(f_{1}+f_{2}\right) \cdot r_{0(t)}+f_{1} \cdot \frac{l p_{(t)}}{f a r_{(t)}}\right\} \\
& +\left(d_{(t)}+w_{(t)}\right) \cdot r_{(t)} \\
& \left.-\tau \cdot d_{(t)} \cdot r_{(t)} /(1-\tau)\right)-\frac{d r_{(t)}}{d t}
\end{aligned}
$$

以上のように，売場面積投資決定に関する理論モデルは，結局（28） 式〜（30）式の連立方程式となる（28）式は，家計と企業の需給 関係からみた単位売場面積の需要を示す関係式で，(29）式は企業 の収益性からみた単位売場面積の最適需要を示す関係式で，（30）式 は単位売場面積と集計売場面積の関係式である。

$$
\begin{aligned}
& \pi_{g(t)}=Z_{g}^{\beta \rho} \cdot\left(\frac{Y_{(t)} \cdot Q_{(t)}}{N_{(t)}}\right)^{1-\rho} \cdot \bar{P}_{(t)}{ }^{\rho} \cdot \kappa_{g(t)}{ }^{\alpha \rho} \\
& \kappa_{g(t)}=\alpha \cdot \rho \cdot \delta_{i} \cdot \pi_{g(t)} \cdot \cos t_{(t)}{ }^{-1} \\
& K_{g(t)}=\mu_{0} \cdot M_{g(t)}{ }^{\mu} \cdot \kappa_{g(t)}{ }^{\mu_{2}}
\end{aligned}
$$

この家計・企業の最適行動を示す同時方程式を基本モデルと位置 付ける. 方程式の解である集計売場面積は, 均衡売場面積（最適） となる，以上のように，資本投資の決定理論に基づいた点で，モデ ル自体の理論的根拠及び説明変数の導入が明確にできる上，計算式 を対数線形化すれば, 回帰式となるため操作しやすい点が本モデル の特徵である，以下，パラメータの推定方法及び適用例を示す.

\section{3. パラメータの推定}

3. 1 入カデータ

本研究の計算例では, 分析時点を 1985 年, 1988 年, 1991 年, 1994 年, 1997 年, 1999 年の合計 6 時点とする. 分析対象都市に関して は，古賀市は 1997 年 10 月に，前原市は 1992 年 10 月に市制を施行 し, また, 島原市は雲仙普賢岳災害時に統計調查が行われなかった ため, 分析時点での統計データの欠如があり，ゆえに本研究では古 賀市，前原市，島原市を除く九州地方の全 81 都市を対象とする.

データ項目及びその出典を表 1 に示す. 入力データには, 各都市 における多時点を対象とした都市別時点別実績デー夕と, 全都市共 通で多時点を対象とした時点別実績データの 2 種類が含まれる.ま た, 売上高営業利益率 $\delta_{i}$ は, 各都市固有なものとして, 以下のよ うに求める.

$$
\delta_{i}=\frac{1}{T} \sum_{t=1}^{T} k_{g(t)} \cdot \frac{1}{T} \sum_{t=1}^{T} \cos t_{(t)} \cdot\left(\frac{1}{T} \sum_{t=1}^{T} \pi_{g(t)}\right)^{-1}
$$

以上のデータをもとに，表 1 の項目について， 81 都市 $\times 6$ 時点の パネルデータを作成した。なお, 地価, 容積率, 単位建設工事費, 建築土地公租公課税率, 損害保険料率, 割引率, 減価償却率の扱い については式 (27) 式より, 建設コスト cost ${ }_{(t)}$ として一変数の扱 いにした。

\section{2 推定方法と結果}

第 2 章で構築した同時方程式モデルは, 計量経済モデルの一種で あり，モデルの推定は一般に回帰分析によって行われる．そして回 
表 1 入カデータの説明

\begin{tabular}{|c|c|c|}
\hline \multicolumn{2}{|c|}{ 外生変数 } & \multirow{2}{*}{ 分析に用いたデータ項目 } \\
\hline 記昘 & 名称 & \\
\hline$\overline{P(t)}$ & 商品平均価格 (物価) & 消費者物価指数 (商品值) \\
\hline$N_{(t)}$ & 小売業店舗数 & 小売業店舗数 \\
\hline$Y_{(t)}$ & 家計所得 & 1 世帯当たり課税対象所得額 \\
\hline$Q_{(1)}$ & 家計総数 & 世帯数 \\
\hline$M_{g(t)}$ & 同業種店舗数 & 同業種店舗数 \\
\hline $\operatorname{cost}(t)$ & 建設コスト & 式(25) \\
\hline$l p_{(t)}$ & 地価 & 都市別平均地価 \\
\hline$f a r_{(i)}$ & 容積率 & 商業地 \\
\hline$r_{o(t)}$ & 単位 $\left(1 \mathrm{~m}^{2}\right.$ 当たり)建設工事費 & 単位建設工事費 (商業用途, 全国値) \\
\hline$f_{i}$ & 建物・土地公租公課税率 & (固定資産税率+都市計画税率) $\times$ 評価率 \\
\hline$f_{2}$ & 損害保険料率 & 損害保険料率 (事務所，一般店舗) \\
\hline$\omega_{(1)}$ & 割引率 & 全国貸出平均金利(長期金利) \\
\hline$d_{(t)}$ & 减価償却率 & 減価償却率 (店舗使途) \\
\hline \multicolumn{2}{|c|}{ 丙生変数 } & \multirow{2}{*}{ 分析に用いたデータ項目 } \\
\hline 記号 & 名称 & \\
\hline$\pi_{g(t)}$ & 単位(1店舗当たり)年間販売額 & 1店舗当たり年間販売額 \\
\hline$k_{g(t)}$ & 単位 (1店舗当たり)売場面積 & 1店舗当たり売場面積 \\
\hline$K_{g(u)}$ & 集計(都市全体の) 坣場面積 & 都市別売場面積 \\
\hline
\end{tabular}

注 : 容皘率は、商業施設の建ぺい军を $80 \%$ と想定し、1階の場合は容穗率が $80 \%$ となる。
表 2 パラメータの推計結果

\begin{tabular}{|c|c|c|}
\hline 式 & 各パラメータの推計結果 & 決定俰数 \\
\hline (26) & 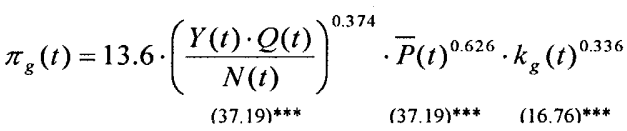 & 0.766 \\
\hline (27) & $k_{g}(t)=\delta_{i} \cdot \pi_{g}(t) \cdot \cos t(t)^{-1}$ & - \\
\hline (28) & $K_{g}(t)=1.000 \cdot M_{g}(t)^{1.000} \cdot k_{g}(t)^{0.999}$ & 0.876 \\
\hline
\end{tabular}

注 : ***は1\%有意，数值は $\mathrm{t}$ 值である。

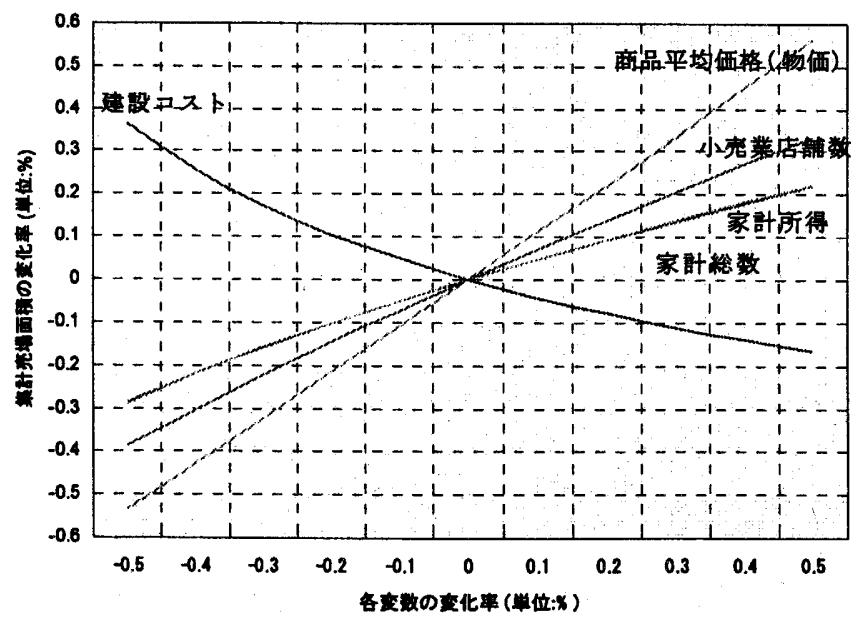

図 1 各決定要因の感度

帰分析の中でも特に通常最小二乗法がよく使われる．ただし，通常 最小二乗法が望ましい性質を持つための条件の一つに，説明変数と 誤差項が相関しないという仮定がある，同時方程式モデルでは，誤 差項と説明変数との間に相関があるため, 通常最小二乗法を用いる と，パラメータの推定にバイアスが生じてしまい，過大推定されて しまう恐れがある．以上のような説明変数と誤差項との相関で生ず る問題を解決するための有力な方法が, 操作変数法や 2 段階最小二 乗法等の同時推定を用いた推定方法である7n。本研究は 2 段階最小
二乗法によりモデルの推定を行う. つまり，モデルに含まれるすべての 外生変数を内生変数に回帰させるこ とによって, 操作变数が求められる. さらに,この操作変数を用いて各構 造方程式を推定する方法である。

モデルのパラメータは，各式を対 数線形化の後，九州地方 81 都市の データを用いて推定を行った。 パラ メータの推定結果を表 2 に示すよう に，す心゙ての符号条件を満足し， $\mathrm{t}$ 值も $1 \%$ 水準で統計的に有意な結果 を得られている。

決定係数については，式（26）は 0.766 で, 式 (28) は 0.876 で高

い值を示していることから，モデル
に導入した説明変数忙要因として妥当であるといえる．また，式（26） のパラメータの值をみると, 商品平均価格 $P_{(t)}$ が 0.626 で最も高く, 単位（1 占舗当り）年間販売額に与える影響が大きいことがわかる.

\section{3 各決定要因の感度分析}

売場面積の決定要因として認められた商品平均価格 (物価)，小売 業店舗数, 家計所得, 家計総数, 建設コストの影響度合を検証する. ここでは，実際のサンプルを用いてモデルのシミュレーションによっ て各要因の感度分析を行った．図-1 は，1999 年のサンプルを用い て，各变数の值を一定率で変化させた場合における集計売場面積の 対象全都市平均値の変化率を示したものである.

図-1に示すように，集計売場面積に対して感度の最も高い変数 は, 商品平均価格 (物価)である.さらに, 現状の水淮 (変化率 $=0 \%$ ) を基準にして，上方・下方へと変化していく感度の違いをみると，建 設コストにおいて上方と下方との差が見られ，現状を上回るときの 感度が低い，つまり，建設コスト低下時の集計売場面積の变化より も，建設コスト上昇時の集計売場面積の変化が小さいことがわかる. ゆえに，建設コストが低下するほど売場面積は増加する傾向にある が，建設コストが上昇しても売場面積それほど減少しない傾向があ ると言える。

\section{4. 理論モデルの適用}

\section{1 九州地方小売業の動向}

ここで，まず 1985 年〜 1999 年に至る小売業売場面積，年間販売 額, 販売効率 (売場面積 $1 \mathrm{~m}^{2}$ 当たりの年間販売額) の動向を通じて, 九州地方の都市における小売業の状況を概観する，なお，デ一タの 出典は経済産業省の商業統計である。

図 2 に示すように，売場面積，年間販売額は 1985 年以降ほぼ一 定の増加傾向を示しているが，1997 年以降，年間販売額は小幅な減 少傾向に転じている．販売効率は1985 年から 1991 年にかけて上昇

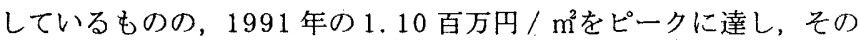
後は低下の一途をたどっている. 1999 年になると, 店舗 1 平米当り の年間販売額は 1985 年を下回っている. 1991 年以降の販売効率の 低下は，バブル期にお゙ける店舗の投資計画がバブル崩壊以降の過剩 投資となり，店舗売場面積が過剩状態に陥ったためであると考えら 


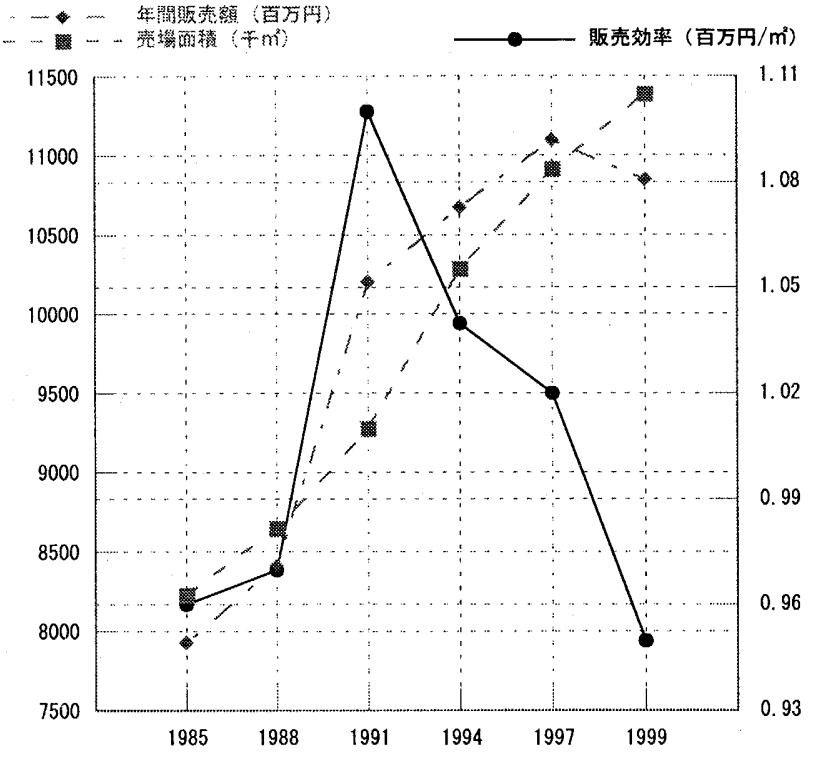

図 2 九州地方における販売効率の動向

れる．以上のように，小売業の低迷は，九州地方においても梁刻な 状況であり，早急な対忘策が必要である。

\section{2 福岡都市圏への適用}

2.2 節で述べたように，モデル構築の前提条件の1つとして，「各 都市に居住する家計は自都市内の商品を消費するものとする」との 仮定を設けている。この仮定に基づくと，県レベル，あるいは都市 圈レベルへの適用例は考えられるが，本研究は都市における適正売 場面積の推計を目的としており，モデルの構築や使用するデー夕は すべて都甫をべースにしている，また，県レベル等に適用する際に いくつかのデータ項目について, 各都书の平均值又は合計值を使用 することになるが，サンプルの数が極端に少なくなり，パラメータ の妥当な值を求めるためには，モデルを再棈筑する必要がある．し たがって，本研究のモデル適用例として，都市レベルのみを対象と する。

具体的には，前節で求まれたパラメータと福岡都市圈の 6 都市の データを用いて，6 時点において各都市の均衡売場面積を推計した。 この均衡売場面積を各都市における小売業最適規模と位置付け, 福

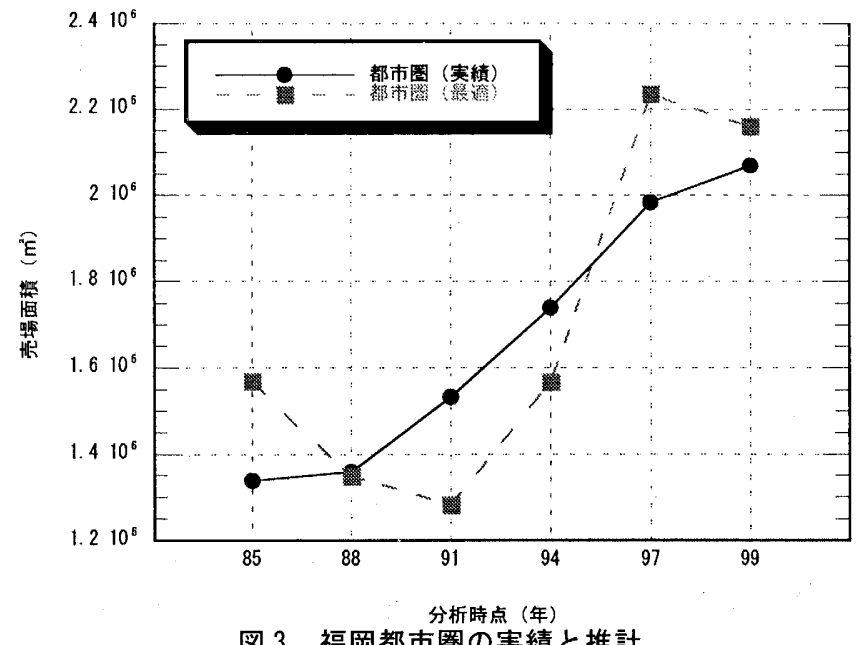

図 3 福岡都市圏の実績と推計
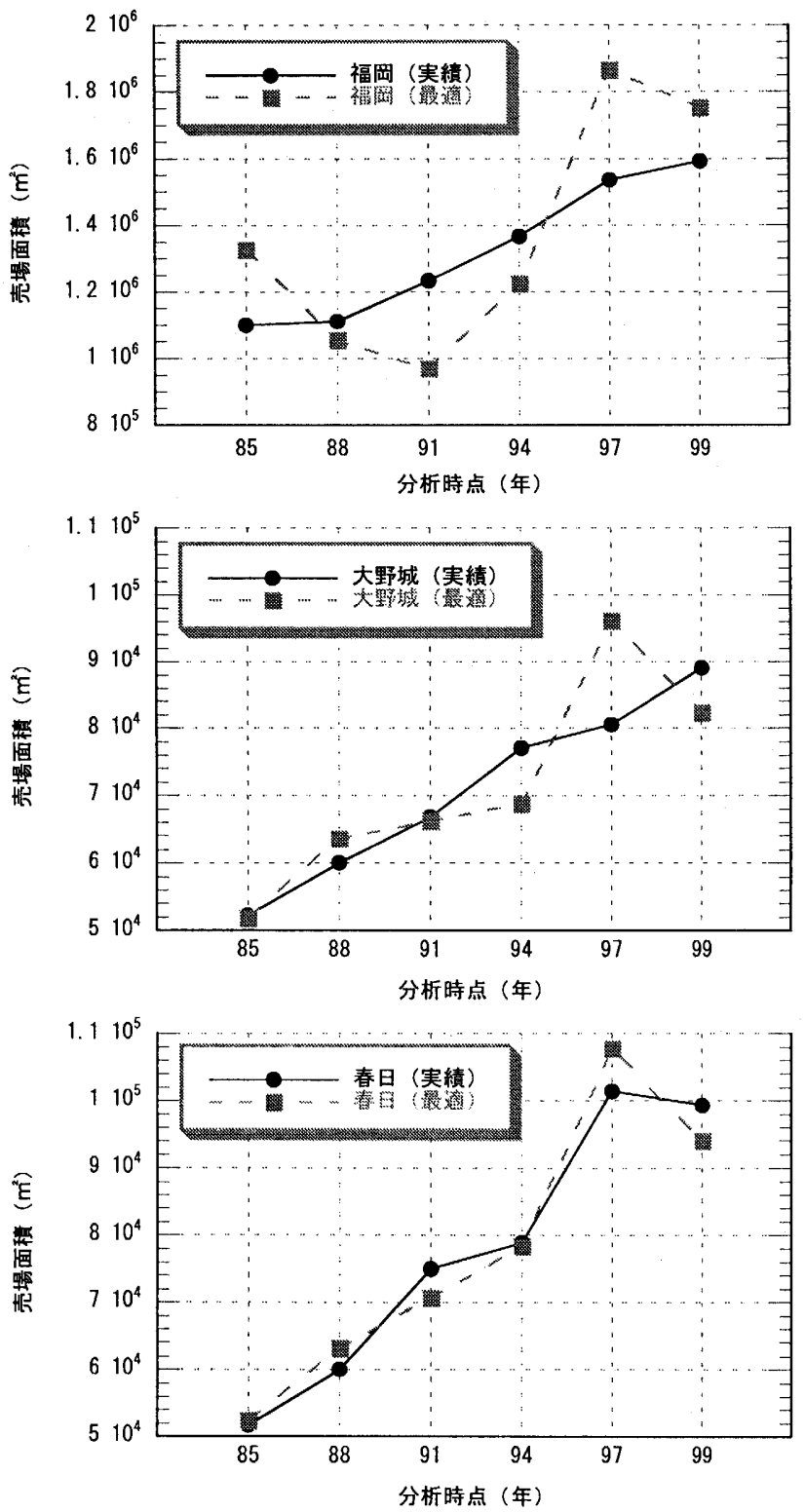

図 4 福岡都市圏の各都市の実績と推計 (1)

岡都市圈及び都市圈各都市の実績規模と比較するる。なお，福岡都市 圈全体の結果は各都市の推計值を総計したものである.

ここで，まず，福岡都市圈全体の結果についてみると，図 3 に示 すように均衡売場面積は，1985 年から1991年にかけて低下してい る.その閒, 1988 年の売場面積の実績規模は，推計規模とほぼ同じ となっている. 1991 年以降は推計規模は上昇し, 1997 年に最大と なり，実績規模を大きく上回った。これは，図 4 に示寺福岡市の推 計結果の傾向と類似しており, 都市圈にお汁る他都市の影響はほぼ 福岡市によって吸収されたかたちとなっている，つまり，都市圈の 商業規模に福岡市の影響がいかに大きいことがわかる.

次いで, 都市圈における各都市の特徵は以下のようにまとめる. 図 4 に示すように, 福岡市の場合, 均衡売場面積の推計規模がバブ ル時期地価の高騰に影響され，1985 年から1991 年にかけて低下し ているが，その後上昇し，1997年にピークに達していた，1999 年 は小幅ではあるが，減少傾向に転じている．また，1988 年から 1994 年頃まで，実績規模が推計規模を上回っており，売場面積は過㮃状 

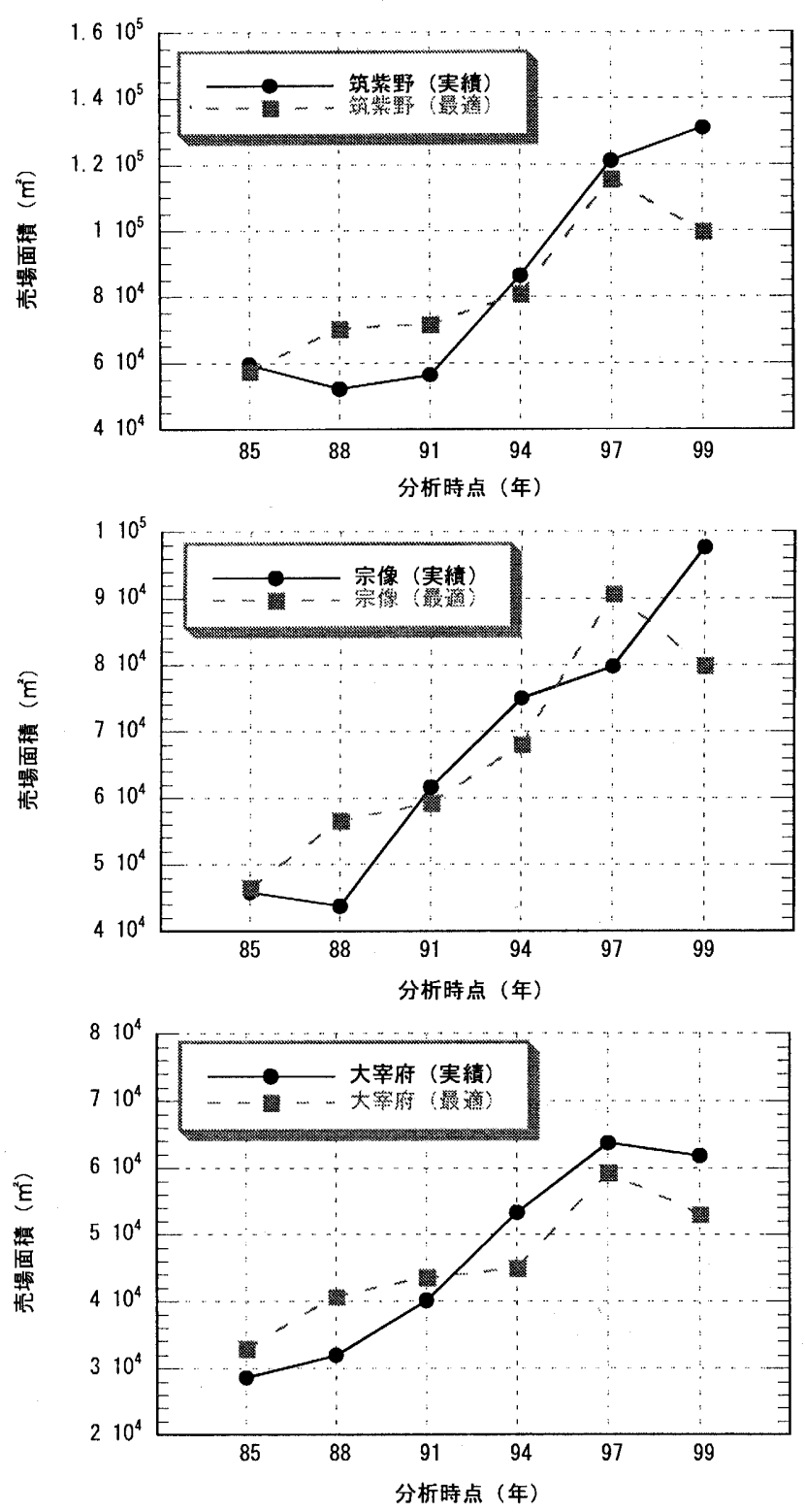

図 5 福岡都市圏の各都市の実績と推計 (2)

態にあったが, 1994 年以降，推計規模が実績規模を大きく上回った たため，今後とも売場面積の增加が予想される.

大野城市，春日市の場合は，1997 年の推計規模と実績規模との差 が比較的に大きいが，他の時点においては，ほぼ一致しているため， この 2 都市は，地価や経済状況の変化の中，小売業売場面積の規模 は，比較的にバランスを取れているといえる.

図 5 に示すように，筑紫野市，宗像市の場合，売場面積の規模は 異なるが，実績と推計規模の変化傾向はほぼ同じである，つまり， 1988 年に売場面積の実績は一度減少したが, それ以降, 推計値とも に增加傾向にあるが，1997 年以降の推計值が減少傾向に転じ，実績 值との差は大きいため，今後売場面積は過剩状態に陥る可能性があ ると考えられる。

大宰府市は 1991 年まで，推計規模は実績規模を上回っており，そ の後逆転したが，実績規模と推計規模の増減はほぼ同じ傾向にあり， また，当市は福剛市の近郊にある観光都市であるため，観光施設等 は広い商圈をもっていることを考慮すると，今後売場面積は過剩状
態になると考えにくい.

以上のように, 福岡都市圈各都市の予測結果の傾向は異なるが, 地価変動等の影響で, 1997 年を境に売場面積の実績值と推計値は大 きく変動するのは特徵である。

\section{5.おわりに}

本稿では，近年小売業販売効率の低下，売場面積入の過剩投資等 に着目し，都市にお括る均衡売場面積を推計する一つのアプローチ として, 新古典派投資理論を考慮して, 家計効用最大化行動, 企業 短期利潤最大化行動，企業長期投資行動の 3 つ行動を定式化し，都 市における小売業最適規模の推計モデルの構築を試みた。

モデルの構築に際しては, 説明変数は投資理論に基づいて導入さ れ，モデル自体は同時回帰式に帰着することにより，モデルの理論 的根拠が明確の上，操作しやすい点は本モデルの特徵である。 また， 九州地方各都市のパネルデータを用いて, パラメータの推定を行っ たが，モデル決定係数の值が高く， $\mathrm{t}$ 值も $1 \%$ 水準で統計的に有意な 結果が得られた。ささらに, 均衡売場面積決定要因の感度分析では, 商品平均価格 (物価) の感度が最も高く, 建設コストにおいては, 現 状水準（変化率 $=0 \%$ ）を基準としたとき，その上方と下方との差が 見られ，現状を上回るときの感度が低いことがわかった．

福岡都市圈への適用では, 推計規模の増减や実績規模との関倸は 都市によって異なる傾向がみられており，今後売場面積の動向及び その問題点を示唆することができたただし，本モデルは経済理論 に基づいた部分が多いため, 計算結果は物価指数や所得などに影響 されやすく，特に福岡市のような大都市においては，地価の上昇や 下落が激しいため, 時点によって計算結果が大きく変動し, 現実と の乘離があると考えられる，また，本モデルの構築は，自都市内の 商品を消費するという前提条件に基づいており，巨大商圈の持つ都 市にモデルを適用する際に，工夫する必要がある，これを今後モデ ル改良の課題としたい。

\section{謝辞}

本研究を進めるにあたって, 九州大学大学院修士修了生の安藤康 隆氏（現 JR 九州株式会社）によるデ一夕作成整理, 及び同氏との 討論に多くを負っている，あらためて謝意を表す次第である。

また，大変丁寧な查読と貴重なご意見を頂いた匿名の査読者には， ここに記して哚く感謝の意を表する.

\section{参考文献}

1）斎藤参郎，本村裕之：不動点アルゴリズムを用いたダイナミカル八フモデ ルの競争的均衡商業床空間分布の計算, 日本都市計画学会学術研究論文集 No27, pp. 451-456, 1992.11

2) 奥村誠，松村憲一：小規模小売店の最適更新行動に関する研究, 土木計画 学研究論文集, No13, pp. 257-264, 1996.8

3) 小林潔司: 非日常的サービスに着目した地方都市活力の変動過程に関する 研究, 日本都市計画学会学術研究論文集 No27, pp. 433-438, 1992.11

4) 朱保華: 投資関数の理論, 九州大学出版会, 1995

5) D. Romer：上級マクロ経済学, 日本評論社, 1998

6) 坂和愛幸: 最適化と最適制御，森北出版，1980

7) Hsiao, C:Analysis of Panel Data, Cambridge Univ. Press, 1986 